\title{
Growth Hormone Receptor
}

National Cancer Institute

\section{Source}

National Cancer Institute. Growth Hormone Receptor. NCI Thesaurus. Code C41017.

Growth hormone receptor (638 aa, $\sim 72 \mathrm{kDa}$ ) is encoded by the human GHR gene. This protein is involved in somatotropin-dependent signaling and generalized growth. 